\title{
A Randomized, Open Label, Comparative Study of Biotin as an Add-On Therapy to Metformin Vs Metformin Alone in Newly Diagnosed Type 2 Diabetes Mellitus Patients
}

\author{
Dr.T.Siyamala Devi ${ }^{1}$, Dr.R.Ranjani ${ }^{2}$ \\ ${ }^{1,2}$ Assistant Professor Department of Pharmacology, Govt. Chengalpattu Medical College \& Hospital, \\ Chengalpattu, Tamil Nadu, India
}

\begin{abstract}
:
Introduction: Type 2 DM is the common form of Diabetes Mellitus. Since there is no complete cure for Type 2 $D M$, there is need for newer and effective alternatives. Biotin increases insulin secretion in pancreas and glycogen synthesis in liver by increasing the expression of Glucokinase.

Objective: To assess the efficacy and tolerability of Biotin as add on therapy to metformin in the management of Type 2 DM in comparison with metformin alone.

Methodology:60patients diagnosed with Type 2 DM attending the outpatient Diabetology department of Stanley Medical College and Hospital were (30 patients in each group) were included in the study.. The study duration comprised of 4 weeks of treatment period and 2 weeks of follow-up. Assessment of efficacy was done by measuring fasting and post prandial blood glucose values at the end of every week.

Results: Both fasting \&postprandial blood glucose values were significantly reduced in GROUP II (Biotin was combined with metformin) from first week onwards and maintained even till 5th week.

Conclusion: Biotin can be safely used as an add on therapy to the existing standard therapy in Type 2 Diabetes Mellitus for better glycemic control without side effects .
\end{abstract}

Keywords: Biotin,Type 2 DM

\section{Introduction}

Diabetes mellitus (DM) refers to a group of common metabolic disorders that share the phenotype of hyperglycemia.(1)

In the United States, diabetes was listed as the seventh leading cause of death in 2007. A recent estimate suggested that diabetes was the fifth leading cause of death worldwide and was responsible for almost 4 million deaths in 2010 ( $6.8 \%$ of deaths were attributed to diabetes worldwide) .India leads the world with largest number of diabetic subjects earning the dubious distinction of being termed the "diabetes capital of the world"(2).

Several distinct types of Diabetes Mellitus (DM) exist. But Type 2 diabetes mellitus is the predominant form of diabetes worldwide, accounting for $90 \%$ of cases globally.

The worldwide prevalence of DM has risen dramatically over the past two decades, from an estimated 30 million cases in 1985 to 285 million in 2010. Based on current trends, the International Diabetes Federation projects that 438 million individuals will have diabetes by the year 2030.Although the prevalence of both type 1 and type $2 \mathrm{DM}$ is increasing worldwide, the prevalence of type $2 \mathrm{DM}$ is rising much more rapidly.

Factors contributing to hyperglycemia in Type 2DM, may include reduced insulin secretion, decreased glucose utilization, and increased glucose production from the liver. (3)

There is a growing need for novel drugs with improved efficacy and less side effects to treat this disease. (4)

\subsection{Scope of the present study}

Glucokinase is an inducible enzyme present in the liver and beta cells of pancreas. In the liver it increases hepatic glucose uptake by inducing glycolysis and glycogen synthesis, as it is involved in the first step of these pathways. In the beta cells of pancreas this sensing leads to glucose induced insulin secretion(5)(6)(7)

It has been found that glucokinase expression is low in Type 2 DM. . GK activators (GKAs) increase the glucose affinity and maximum velocity (Vmax) of GK.(8)(9)

Biotin is a water soluble vitamin. Recent research findings in animals and humans indicate that biotin increases the expression of Glucokinase at pharmacological doses $(9-16 \mathrm{mg})$ and there by helps in reducing blood glucose in type 2 DM. Recent reports about biotin's ability to substantially lower fasting \& post 
prandial glucose levels in Type 2 diabetics, and to do so without side effects, renewed our interest in this $\operatorname{vitamin}(10)(11)(12)(13)$.

So it was decided to conduct a trial to find out the glucose lowering effect of biotin as an add- on therapy with standard treatment.

\section{Objectives}

The present study assessed the efficacy and safety \&tolerability ofBiotin as an add-on therapy to metformin in newly diagnosed cases of Type 2 DM

\section{Materials And Methods}

This was a randomized, open label, prospective,controlled study. The study was started after obtaining the approval from the Institutional Ethical Committee and conducted according to good clinical practice guidelines.Adult patients diagnosed with Type 2 Diabetes Mellitus attending outpatient DiabetologyDepartment of Stanley Medical College were recruited between january 2012 and December 2012. Written informed consent were obtained from the patients willing to participate in the study, in the prescribed format in the regional language. Patients who gave written informed consent were screened by detailed medical history, physical examination and laboratory investigations. Patients who fulfilled the following selection criteria were included in the study.

\subsection{Inclusion criteria:}

1. Newly diagnosed cases of Type $2 \mathrm{DM}$ with Fasting blood glucose (126-150mg/dl) and Post prandial blood glucose (200-250mg/dl).

2. Both male and female patients.

3. Age 30-65yrs.

4. Patients having mild hypertension and dyslipidemia were also included in the study.

5. Patients without complications.

\subsection{Exclusion criteria:}

1. All cases of Type 1 DM.

2. Age below 30yrs and above 65yrs of old.

3. Patients associated with renal and liver disease.

4. Patients associated with ischemic heart disease.

5. Patients who are on anticonvulsant therapy.

6. Pregnant and lactating women.

\subsection{Recruitment \& randomisation:}

Sixty subjects who fulfilled the following eligibility criteria were included in the study. They were randomized into 2 groups(30 patients in group I and 30 patients in group II) by using computer generated random numbers. The study duration comprised of 4 weeks of treatment and 2 weeks follow-up.

Patients in Group I were given tablet metfomin $500 \mathrm{mg}$ OD for 6 weeks. Patients in Group II were given Tab. metfomin $500 \mathrm{mg}$ OD along with Tab. Biotin 5mg BD for 4 weeks. Both tablets were taken after food. At the end of 4 weeks biotin was withdrawn and tablet metfomin $500 \mathrm{mg}$ OD alone was given for next 2 weeks.

Routine hematological investigations, were done before and at the end of the study.

\begin{tabular}{|l|l|l|l|}
\hline GROUP & DRUGS & DURATION & FOLLOW- UP \\
\hline I & Metformin 500mg OD & 4 weeks & 2weeks \\
\hline II & Metformin 500mg OD+ Biotin 5mg BD & 4 weeks & 2weeks \\
\hline
\end{tabular}

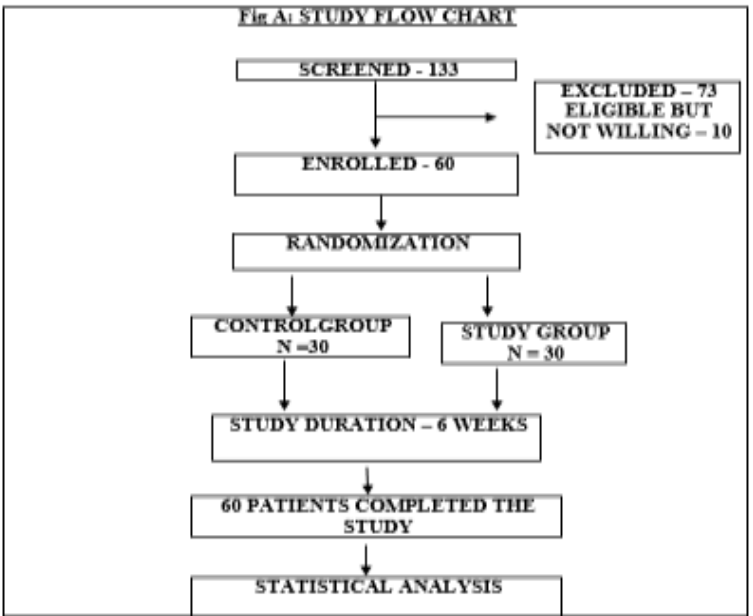


A Randomized, Open Label, Comparative Study of Biotin as an Add-on Therapy to Metformin Vs...

\subsection{Assessment of efficacy}

Blood glucose estimation both Fasting and Postprandial blood glucose levels (after 2hrs of food intake) were done in both groups at weekly intervals till the end of 6 weeks .

\subsection{Assessment of safety}

It was done by history,and by assessing laboratory parameters .Causality analysis of Adverse drug reactions was done by naranjo's algorithm .

Results of both the comparative studies were analysed statistically bySPSS 21.0

\section{Results}

Patients who completed the study alone taken for statistical analysis. There were 2 dropouts in group I and 4 dropouts in group II.

Tables 1,2,3 show demographic features of the patients. The mean age( yrs) in groups I \& II were 45.29 and 47.04 respectively as shown in table No.1. Statistical analysis was done by using student independent $t$ -test and the $\mathrm{p}$ value was not significant $(\mathrm{P}=0.331)$. There was even distribution of age in both the groups. Table No.2 shows, the sex distribution in both the groups. Statistical analysis was done using Chi-Square Test and the $\mathrm{p}$ value was not significant. Out of 28 patients in group I, 12 were male and 16 were female. In group II, 13 were male and 13 were female. There was no significantdifference in the sex distribution between the two groups. $(\mathrm{P}=$ 0.599). Table: 3 shows Body Mass Index of the patients from both the groups. Statistical analysis by student $t-$ test shows no significant difference between 2 groups $(\mathrm{P}=0.108)$.

Table 1: Age Distribution

\begin{tabular}{|l|l|l|l|l|}
\hline Group & N & Mean & SD & Student independent t-test \\
\hline Control & 28 & 45.29 & 6.627 & $\mathrm{P}=0.331$ \\
\cline { 1 - 4 } Study & 26 & 47.04 & 6.478 & \\
\hline
\end{tabular}

${ }^{*} \mathrm{P} \leq 0.05$ significant ${ }^{* *} \mathrm{P} \leq 0.01$ highly significant,${ }^{* * *} \mathrm{P} \leq 0.001$ very high significant.

Table 2: Sex Distribution

\begin{tabular}{|l|l|l|l|l|l|}
\hline \multirow{2}{*}{ Sex } & \multicolumn{2}{|l|}{ Control } & \multicolumn{2}{|c|}{ Study } & \multirow{2}{*}{ Pearson Chi-square test } \\
\cline { 2 - 5 } & $\mathrm{N}$ & $\%$ & $\mathrm{~N}$ & $\%$ & \\
\hline Male & 12 & $42.9 \%$ & 13 & $50.0 \%$ & \multirow{2}{*}{$\mathrm{X} 2=0.277 \quad, \mathrm{P}=0.599$} \\
\hline Female & 16 & $57.1 \%$ & 13 & $50.0 \%$ & \\
\hline Total & 28 & $100 \%$ & 26 & $100 \%$ & \\
\hline
\end{tabular}

${ }^{*} \mathrm{P} \leq 0.05$ significant,${ }^{* *} \mathrm{P} \leq 0.01$ highly significant,${ }^{* * *} \mathrm{P} \leq 0.001$ very high significant

Table 3: Body Mass Index Distribution

\begin{tabular}{|l|l|l|l|l|l|}
\hline $\begin{array}{l}\text { Body } \\
\text { Mass } \\
\text { index }\end{array}$ & Group & $\mathrm{N}$ & Mean & SD & Student independent t-test \\
\cline { 2 - 5 } & Control & 28 & 31.900 & 2.2986 & $\mathrm{P}=0.108$ \\
\cline { 2 - 5 } & Study & 26 & 32.881 & 2.0858 & \\
\hline
\end{tabular}

* $\mathrm{P} \leq 0.05$ significant,${ }^{* *} \mathrm{P} \leq 0.01$ highly significant, ${ }^{* * *} \mathrm{P} \leq 0.001$ very high significant

Table 4 \& Figure 4 show comparison of mean reductionin fasting blood glucose values at weekly intervals. There is more reduction in study group compared to control group which is statistically highly significant from visit 1 to visit 4 . At the end of 4 weeks biotin was withdrawn from study group and the mean reduction is still significant at visit 5 . But the reduction is not significant at visit 6 .

Table 4: Fasting Blood Glucose

\begin{tabular}{|l|l|l|l|l|l|}
\hline \multirow{2}{*}{$\begin{array}{l}\text { Fasting } \\
\begin{array}{l}\text { Blood } \\
\text { glucose }\end{array}\end{array}$} & Control & Study & $\begin{array}{l}\text { Student independent } \\
\text { t-test }\end{array}$ \\
\cline { 2 - 5 } & Mean & SD & Mean & SD & \\
\hline baseline & 137.61 & 4.383 & 136.38 & 5.382 & $\mathrm{P}=0.363$ \\
\hline Visit1 & 133.11 & 4.383 & 129.08 & 4.604 & $\mathrm{P}=0.002 * *$ \\
\hline Visit2 & 127.71 & 2.930 & 121.77 & 4.493 & $\mathrm{P}=0.001$ *** \\
\hline Visit3 & 122.21 & 2.299 & 116.42 & 4.493 & $\mathrm{P}=0.001$ *** \\
\hline Visit4 & 118.25 & 2.429 & 109.92 & 4.279 & $\mathrm{P}=0.001 * * *$ \\
\hline Visit5 & 116.07 & 2.581 & 111.08 & 4.569 & $\mathrm{P}=0.001$ *** \\
\hline Visit6 & 113.50 & 2.835 & 112.90 & 3.266 & $\mathrm{P}=0.087$ \\
\hline
\end{tabular}

* $\mathrm{P} \leq 0.05$ significant,${ }^{* *} \mathrm{P} \leq 0.01$ highly significant , *** $\mathrm{P} \leq 0.001$ very high significant 


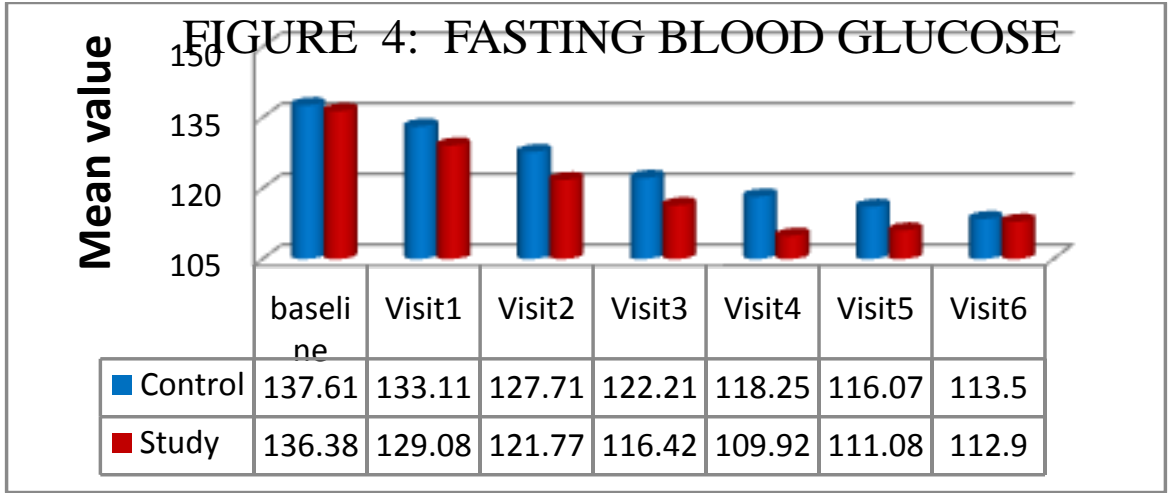

Table 5 \& Figure 5 show comparison of percentage reduction in fasting blood glucose values between both the groups. Which is statistically highly significant from visit 1 to visit 5.But the percentage reduction is not significant at visit 6

Table 5: Percentage Reduction In Fasting Blood Glucose

\begin{tabular}{|c|c|c|c|c|c|}
\hline \multirow{2}{*}{$\begin{array}{l}\text { Fasting Blood } \\
\text { glucose-reduction } \\
\text { percentage }\end{array}$} & \multicolumn{2}{|l|}{ Control } & \multicolumn{2}{|l|}{ Study } & \multirow{2}{*}{$\begin{array}{l}\text { Student independent } \\
\text { t-test }\end{array}$} \\
\hline & $\operatorname{Mean}(\%)$ & SD & Mean $(\%)$ & SD & \\
\hline Visit1 & 3.264 & 1.354 & 5.337 & 1.245 & $\mathrm{P}=0.001 * * *$ \\
\hline Visit2 & 7.156 & 1.387 & 10.698 & 1.498 & $\mathrm{P}=0.001 * * *$ \\
\hline Visit3 & 11.132 & 2.156 & 14.615 & 1.371 & $\mathrm{P}=0.001 * * *$ \\
\hline Visit4 & 13.998 & 2.829 & 19.370 & 2.201 & $\mathrm{P}=0.001 * * *$ \\
\hline Visit5 & 15.600 & 2.217 & 18.524 & 2.442 & $\mathrm{P}=0.001 * * *$ \\
\hline Visit6 & 17.461 & 2.704 & 18.002 & 1.725 & $\mathrm{P}=0.067$ \\
\hline
\end{tabular}

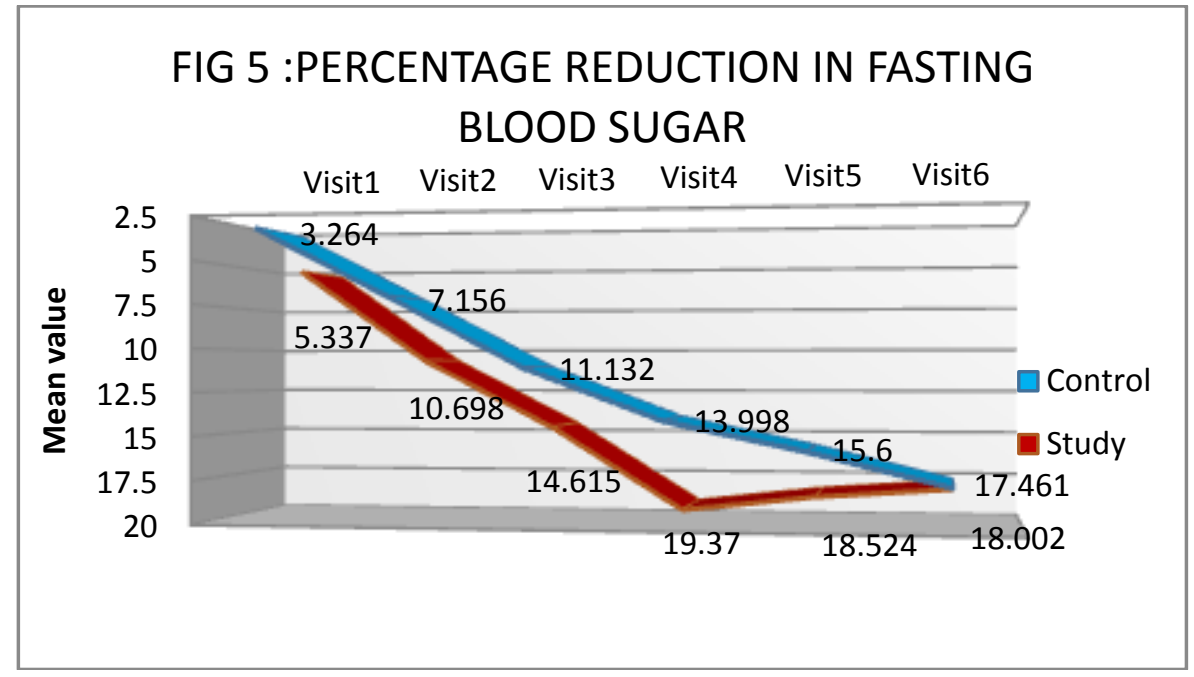

Similarly Table 6 \& Figure 6 and Table 7 \& Figure 7 show comparison of mean reduction in Post prandial blood glucose and percentage reduction in Post prandial blood glucose values in both the groups. The reduction is more in study group compared to control group which is statistically significant from visit 1 to visit5. But p-value is not significant at visit 6.

Table 8 shows the basic hematological investigations before and after the study in both the groups. Paired $t$ test is used for analysis. There is no significant change between baseline and at the end of the study values. 
A Randomized, Open Label, Comparative Study of Biotin as an Add-on Therapy to Metformin Vs...

Table 6: Post Prandial Blood Glucose

\begin{tabular}{|c|c|c|c|c|c|}
\hline \multirow{2}{*}{$\begin{array}{l}\text { Post prandial } \\
\text { Blood glucose }\end{array}$} & \multicolumn{2}{|l|}{ Control } & \multicolumn{2}{|l|}{ Study } & \multirow{2}{*}{$\begin{array}{l}\text { Student independent } \\
\text { t-test }\end{array}$} \\
\hline & Mean & SD & Mean & SD & \\
\hline Baseline & 238.82 & 10.180 & 240.19 & 11.496 & $\mathrm{P}=0.644$ \\
\hline Visit1 & 227.68 & 10.155 & 219.77 & 12.248 & $\mathrm{P}=0.012 *$ \\
\hline Visit2 & 214.93 & 8.927 & 200.62 & 11.179 & $\mathrm{P}=0.001 * * *$ \\
\hline Visit3 & 202.07 & 7.769 & 186.65 & 10.932 & $\mathrm{P}=0.001 * * *$ \\
\hline Visit4 & 192.86 & 6.473 & 176.85 & 12.483 & $\mathrm{P}=0.001 * * *$ \\
\hline Visit5 & 184.82 & 6.219 & 178.58 & 11.053 & $\mathrm{P}=0.013^{*}$ \\
\hline Visit6 & 180.00 & 6.458 & 179.02 & 10.605 & $\mathrm{P}=0.421$ \\
\hline
\end{tabular}

$* \mathrm{P} \leq 0.05$ significant , ** $\mathrm{P} \leq 0.01$ highly significant,$* * * \mathrm{P} \leq 0.001$ very high significant

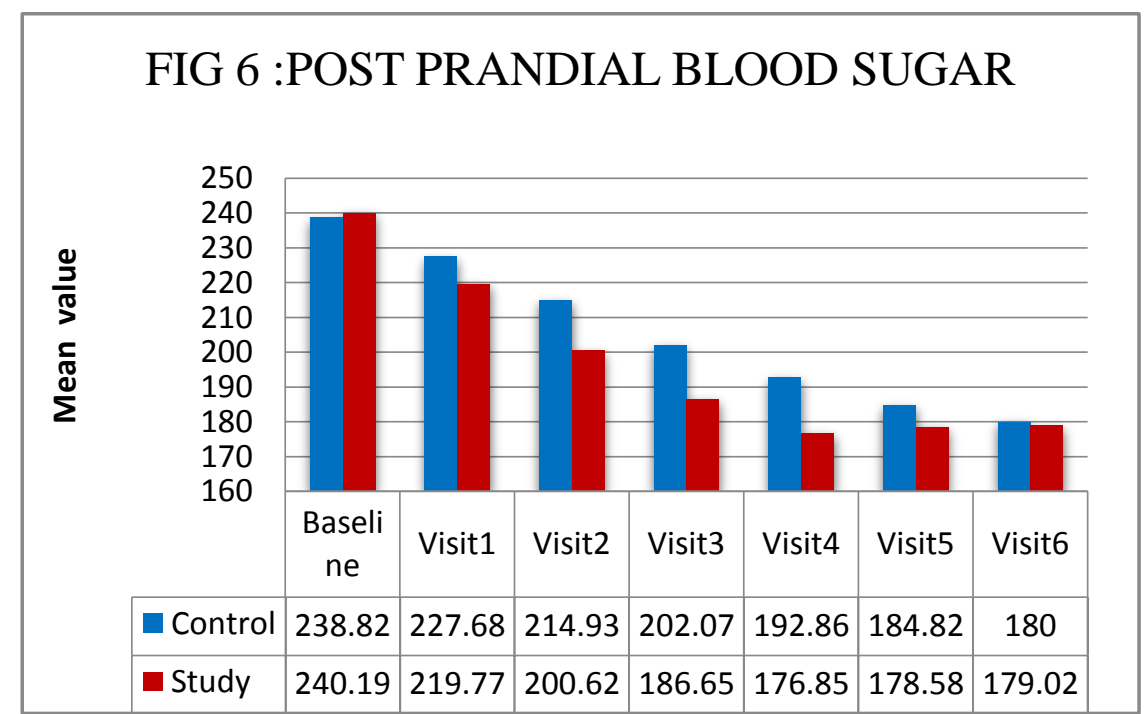

Table 7: Percentage Reduction In Post Prandial Blood Glucose

\begin{tabular}{|c|c|c|c|c|c|}
\hline \multirow{2}{*}{$\begin{array}{ll}\text { PPBS- } & \text { reduction } \\
\text { percentage } & \end{array}$} & \multicolumn{2}{|l|}{ Control } & \multicolumn{2}{|l|}{ Study } & \multirow{2}{*}{$\begin{array}{l}\text { Student } \\
\text { independent t-test }\end{array}$} \\
\hline & Mean & SD & Mean & SD & \\
\hline Visit1 & 4.673 & 0.392 & $\begin{array}{l}8 \\
.524\end{array}$ & 1.813 & $\mathrm{P}=0.001 * * *$ \\
\hline Visit2 & 9.972 & 2.229 & 16.484 & 2.275 & $\mathrm{P}=0.001 * * *$ \\
\hline Visit3 & 15.329 & 2.698 & 22.305 & 2.365 & $\mathrm{P}=0.001 * * *$ \\
\hline Visit4 & 19.167 & 2.838 & 26.396 & 3.541 & $\mathrm{P}=0.001 * * *$ \\
\hline Visit5 & 22.533 & 2.789 & 25.672 & 2.641 & $\mathrm{P}=0.001$ *** \\
\hline Visit6 & 24.559 & 2.720 & 24.272 & 2.380 & $\mathrm{P}=0.681$ \\
\hline
\end{tabular}

$* \mathrm{P} \leq 0.05$ significant,$* * \mathrm{P} \leq 0.01$ highly significant , $* * * \mathrm{P} \leq 0.001$ very high significant

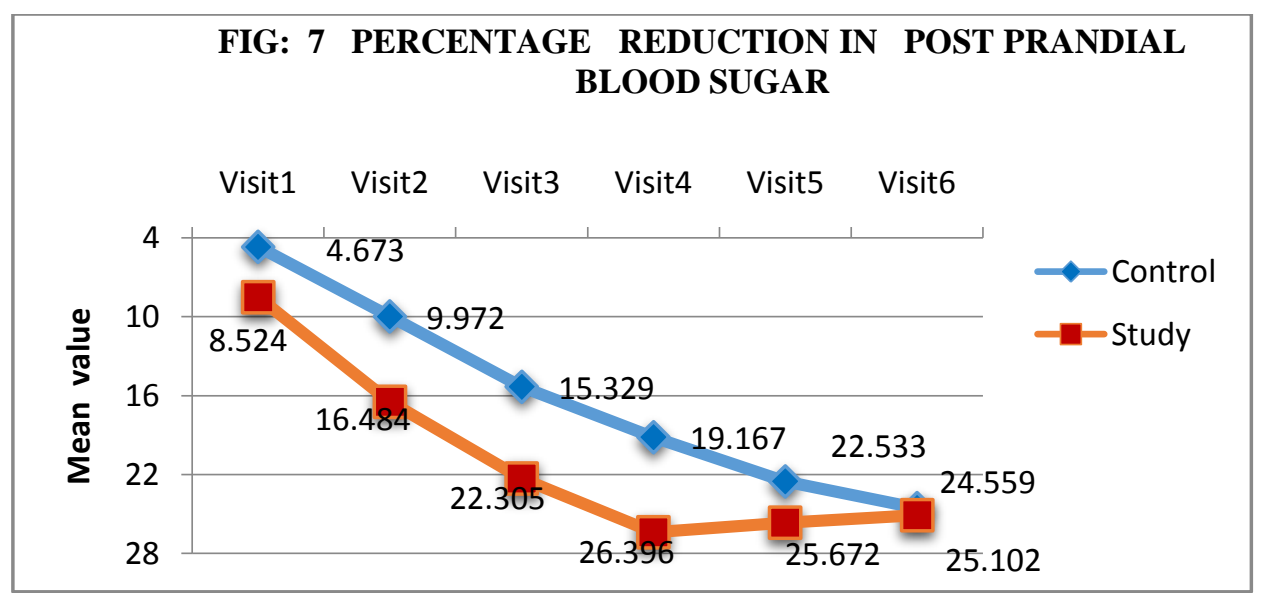


Table 8: Adverse events

\begin{tabular}{|l|l|l|}
\hline Adverse events & Group I & Group II \\
\hline Nausea & 2 & 1 \\
\hline Loose stools & 1 & 0 \\
\hline Gastric irritation & 8 & 7 \\
\hline
\end{tabular}

Table 8 shows the occurrence of adverse effects in both the groups. There is no significant difference between groups.

Table 9 : Basic Hematological Investigations Before And After The Study

\begin{tabular}{|l|l|l|l|l|l|l|}
\hline \multirow{2}{*}{ Parameter } & Group & \multicolumn{2}{|l|}{ Baseline } & \multicolumn{2}{l}{ End of study } & $\begin{array}{l}\text { Student } \\
\text { Paired } \\
\text { t-test }\end{array}$ \\
\cline { 3 - 7 } & & Mean & SD & Mean & SD & \\
\hline \multirow{2}{*}{ Hb } & Group I & 11.18 & .97 & 11.09 & .97 & $\mathrm{P}=0.41$ \\
\cline { 2 - 7 } & Group II & 10.98 & .97 & 11.26 & 1.07 & $\mathrm{P}=0.33$ \\
\hline \multirow{2}{*}{$\begin{array}{l}\text { Total } \\
\text { Wbc } \\
\text { count }\end{array}$} & Group I & 9933.33 & 1669.87 & 9937.04 & 1568.23 & $\mathrm{P}=0.97$ \\
\cline { 2 - 7 } & Group II & 9092.86 & 1614.04 & 9528.57 & 1864.26 & $\mathrm{P}=0.35$ \\
\hline ESR & Group I & 11.74 & 1.46 & 11.56 & 1.37 & $\mathrm{P}=0.13$ \\
\cline { 2 - 7 } & Group II & 11.68 & 1.36 & 11.57 & 1.45 & $\mathrm{P}=0.75$ \\
\hline \multirow{2}{*}{ Urea } & Group I & 21.22 & 2.26 & 20.93 & 2.85 & $\mathrm{P}=0.90$ \\
\cline { 2 - 7 } & Group II & 21.11 & 2.96 & 21.19 & 2.85 & $\mathrm{P}=0.83$ \\
\hline \multirow{2}{*}{$\begin{array}{l}\text { Serum } \\
\text { creatinine }\end{array}$} & Group I & 0.78 & 0.13 & 0.77 & 0.13 & $\mathrm{P}=0.32$ \\
\cline { 2 - 7 } & Group II & 0.77 & 0.14 & 0.77 & 0.13 & $\mathrm{P}=0.77$ \\
\hline \multirow{2}{*}{ SGOT } & Group I & 17.63 & 4.37 & 17.09 & 4.48 & $\mathrm{P}=1.00$ \\
\cline { 2 - 7 } & Group II & 18.00 & 4.46 & 18.07 & 4.50 & $\mathrm{P}=0.96$ \\
\hline \multirow{2}{*}{ SGPT } & Group I & 17.81 & 3.84 & 17.70 & 4.10 & $\mathrm{P}=0.21$ \\
\cline { 2 - 7 } & Group II & 17.36 & 4.08 & 17.86 & 4.62 & $\mathrm{P}=0.66$ \\
\hline
\end{tabular}

$* \mathrm{P} \leq 0.05$ significant , ** $\mathrm{P} \leq 0.01$ highly significant , *** $\mathrm{P} \leq 0.001$ very high significant

There is no significant mean score changes in basic laboratory parameters between start and end of the study.

\section{Discussion}

Biotin is water soluble vitamin..The mechanisms by which biotin lowers the blood glucose can be attributed to actions like stimulation of glucose-induced insulin secretion, enhancing insulin sensitivity, and the acceleration of glycolysis in the liver and pancreas by its enhancement of the enzyme, glucokinase.

In several animal models of type 2 diabetes mellitus and in few human studies, it was found that biotin lowered blood glucose levels and improved the results of glucose tolerance tests.

The daily requirement of biotin is 150-300 microgram / day. Presently high oral dose of biotin is given to treat Multiple carboxylase deficiency In this study high oral dose which can be called as pharmacological dose of biotin $5 \mathrm{mg}$ BD was used. Biotin is completely absorbed even when pharmacological doses are administered.

Biotin $5 \mathrm{mg}$ BD was administered with metformin $500 \mathrm{mg}$ OD in newly diagnosed cases of Type $2 \mathrm{DM}$ and its effects were compared with control group who were receiving only metformin $500 \mathrm{mg}$ OD.

From the results both fasting and postprandial blood glucose values were significantly reduced in GROUP II ( BIOTIN was combined with metformin ) from first week onwards and maintained even till 5th week.( i.e even after withdrawal of BIOTIN at the end of $4^{\text {th }}$ week).

Similarly percentage reduction of both fasting and postprandial blood glucose were more in group II where BIOTIN was added to metformin. This difference is statistically significant from first week onwards and it is maintained even till 5 th week..

Biotin didn't significantly alter the haematological parameters such as Hb ,Total WBC count ,ESR, Renal \& liver function tests.

Adverse events were mild of which gastric irritation was most commonly noted, followed by nausea, loose stools which were mainly due to metformin . Adverse effects were similar between the groups. No serious adverse events were observed in both the groups.

Since biotin improved the glycemic control without causing adverse effects, it can be safely administered as an add on therapy in Type 2 Diabetes mellitus. 
This was in correlation with the results of previous human studies where biotin reduces blood sugar significantly.(14)(15)

Biotin also has shown beneficial effects in diabetic neuropathy, dyslipidemia associated with Type 2 DM in recent human trials.(16)(17)(18)

Patients with Type $2 \mathrm{DM}$ are also prone for nutritional deficiency of biotin manifesting as dermatitis , alopecia. So multiple benefits can be obtained by patients with Type $2 \mathrm{DM}$.

Limitations of this study are small samlple size and short duration. There are no studies on long term effects of biotin on blood glucose levels in Type 2 DM and there are only few studies on beneficial effects of biotin in diabetic neuropathy and dyslipidemia associated with .

Trials on these will throw further light on its blood glucose lowering effect and other beneficial effects.

\section{Conclusion}

From the outcome of the study it has been concluded that biotin can be safely used as an add on therapy to the existing standard therapy in type 2 Diabetes Mellitus for better glycemic control without side effects . Further studies are needed to confirm this.

No conflict of interest

\section{Conflict Of Interest}

\section{References}

[1]. Alvin. C . powers, Diabetes Mellitus ,Harrison's principles of internal medicine chap: 338,17 th ed. page .no 7083

[2]. V.mohan s. Sandeep Epidemiology of type 2 diabetes: Indian scenario ,Indian journal of medical research, 125, March 2007, pp 217-230

[3]. Alvin. C . powers, Diabetes Mellitus ,Harrison's principles of internal medicine ch 338,17th ed. page .no 7084

[4]. Henry M. Kronenberg, MD,Shlomo Melmed, MD, FRCP,Kenneth S. Polonsky, MD,

[5]. Chap 30 Type 2 diabetes mellitus, Williams Textbook of Endocrinology, 11th ed.

[6]. Hariharan .N farrely. D,expression of hepatic glucokinase decrease the glucose level,, Diabetes 1997 jan 46: 11-6

[7]. Mc carty MF Med Hypothesis 1999 may:52(5):401-6

[8]. BIOTIN ,Vita longevity, Orientreih foundation for the advancement of science Inc. June 2004

[9]. Romero, German biotin regulation of pancereatic glucokinase. Endocrinology 1999 oct $140: 4555-600$

[10]. PajolA Riu E, correction of diabetic alteration by glucokinase. Proc Natl Acad science 1996 jul9:93(14):7225-30

[11]. Fernandez C ,pharmacological effects of biotin ,J nutri Biochemistry 2005 jul 6 (700:424-7

[12]. Koutsikos D, Agroyannis B, biotin status and plasma glucose in diabetes , Ann Nutrition Y Academic Science 1985:447;389-392

[13]. Maheashi M, ,MakinoY Therapeutic evaluation of biotin on hyperglycemia,J Clinica Bio Chemic Nutrition 193:14;211-18

[14]. Zhang $\mathrm{H}$, osada $\mathrm{k}$, Sone $\mathrm{H}$, Biotin administration improves the impaired glucose tolerance in streptozotocin-induced diabetes rats, $\mathrm{j}$ nutri sci vitaminol 199997:43:271-280

[15]. Cogge shall J c, Heggerts biotin status and plasma glucose in diabetes .Ann N Y Acad Sci 1985;447:389-392

[16]. Maebashi M Makinoy,Furukawa Y, Therapeutic evaluation of biotin on hypperglycemia in patients with non-insulin dependent diabetes mellitus. J of Bio Che nutriyion 1993;14;211-218

[17]. Koutsikos D Biotin for diabetic peripheral neuropathy , Biomed pharmacotherapy 1990,44(10):511-4

[18]. Revilla -Monsalve, Biotin supplementation reduces the plasma triglyceride and VLDL in TYPE 2 DM ,Biomed Pharmacother.2006May;60(4):182-5.Epub2006 Mar 31 